\title{
УДОСКОНАЛЕННЯ УПРАВЛІННЯ КОНКУРЕНТОСПРОМОЖНІСТЮ ПІДПРИЄМСТВА
}

\section{IMPROVING THE COMPETITIVENESS MANAGEMENT OF THE ENTERPRISE}

УДК 658.8:339.137.2

DOI: https://doi.org/10.32843/infrastruct51-14

\section{Бондаренко С.M.}

к.е.н., доцент,

доцент кафедри менеджменту

та публічного адміністрування

Київський національний університет технологій та дизайну

Бодько Є.С.

студентка

Київський національний університет технологій та дизайну

Кравченко С.C.

студент

Київський національний університет

технологій та дизайну

Bondarenko Svitlana

Kyiv National University

of Technologies and Design

Bodko Elizaveta

Kyiv National University

of Technologies and Design

Kravchenko Semen

Kyiv National University

of Technologies and Design у статmі розглянуто питання вдосконалення управління конкурентоспроможністю підприємства. Наведено основні визначення конкурентоспроможності. Проаналізовано внутрішні та зовнішні чинники впливу на конкурентоспроможність підприємства. Зовнішні чинники поділяються на чинники макрорівня та мезорівня. Внутрішні, або чинники мікрорівня, відносяться до продукції і послуг та до системи господарювання підприємства. В умовах глобалізаціі та широкого розповсюдження інформаційних технологій забезпечувати конкурентоспроможність підприємству дає змогу вміння ефективно використовувати свої нематеріальні конкурентні переваги. Вагомого значення набувають ті види ресурсів, які не мають матеріальної форми, проте вирішальною мірою впливають на фрормування результатів діяльності підприємства. Конкурентоспроможність орормується на етапах життєвого циклу товарів під дією внутрішніх та зовнішніх умов. Для цього необхідно здійснити впровадження інновацій. Запропоновано заходи з удосконалення управління конкурентоспроможністю підприємства.

Ключові слова: конкурентоспроможність, управління, чинник, інновація, підприємство.

В статье рассмотрены вопросы совершенствования управления конкурентоспособ- ностью предприятия. Приведены основные определения конкурентоспособности. Проанализированы внутренние и внешние факторы влияния на конкурентоспособность предприятия. Внешние оракторь делятся на фракторы макроуровня и мезоуровня. Внутренние, или фоакторы микроуровня, относятся к продукции и услугам и к системе хозяйствования предприятия. В условиях глобализации и широкого распространения информационных технологий обеспечивать конкурентоспособность предприятию позволяет умение эффективно использовать свои нематериальные конкурентные преимущества. Большое значение приобретают виды ресурсов, которые не имеют материальной формы, однако в решающей степени влияют на формирование результатов деятельности предприятия. Конкурентоспособность формируется на этапах жизненного цикла товаров под действием внутренних и внешних условий. Для этого необходимо осуществить внедрение инноваций. Предложены меры по совершенствованию управления конкурентоспособностью предприятия.

Ключевые слова: конкурентоспособность, управление, фрактор, инновация, предприяmue.

The article considers the issues of improving the management of enterprise competitiveness. The definitions of the enterprise's competitiveness are analyzed, the interpretations of domestic and foreign economists are given. It was noted that the competitiveness of the enterprise characterizes possibility and effectiveness of adaptation of the enterprise to the conditions of the external competitive environment, the ability to compete in this market and win in it. The competitiveness of the enterprise is influenced by internal and external factors. External factors are divided into macro-level factors, which include economic, political, social, demographic, cultural, technological, geographical, environmental, scientific and technical, epidemiological, as well as meso-level factors that manifest themselves as industry barriers. These are suppliers, consumers, competitors, intermediaries, government agencies, local communities and others. Internal factors of influence, or micro-level factors are divided into factors that relate to products and services, and factors that relate to the management system of the enterprise. In the context of globalization and the widespread use of information technology to ensure the competitiveness of the enterprise allows the ability to effectively use their intangible competitive advantages. Important are those types of resources that do not have a material form, but have a decisive influence on the formation of the results of the enterprise. The value of material resources gradually decreases, while intangible assets, such as the reputation of the firm, corporate and organizational culture, etc., are constantly growing. Competitiveness is formed at the stages of the life cycle of goods under the influence of internal and external conditions. But for this it is necessary to implement innovations. Therefore, it can be argued that the introduction of innovations is a method of creating the competitiveness of the enterprise. Measures have been proposed to stimulate the competitiveness of the enterprise in order to improve its economic performance in the long run.

Key words: competitiveness, management, factor, innovation, enterprise.

Постановка проблеми. Інтеграція економіки України у світове господарство висунула жорсткі вимоги до підвищення конкурентоспроможності вітчизняної продукції та їх виробників на внутрішньому та світовому ринках. На глобалізованому насиченому ринку підприємства України мають бути конкурентоспроможними, що забезпечить зміцнення їхніх конкурентних позицій та вплине на ринкову ситуацію шляхом пропозиції якісної продукції чи послуг, більш повного задоволення вимог споживачів і забезпечення високої ефективності функціонування. Ринкова конкуренція ставить перед підприємствами завдання пристосування до вимог мінливого конкурентного середовища фуннкціонування, зокрема завдяки вдосконаленню управління їхньою конкурентоспроможністю.
Аналіз останніх досліджень і публікацій. Завдяки активному інтересу до проблем підвищення конкурентоспроможності суб'єктів господарювання, що виник унаслідок розвитку ринкових відносин, з'явилася велика кількість розробок, спрямованих на вирішення цієї проблеми. У науковій літературі вивченню конкурентоспроможності присвячено велику кількість робіт українських та зарубіжних учених. Зокрема, дослідженням даної теми займалися: Г. Азоєв, Л. Балабанова, Н. Валінкевич, А. Касич, С. Клименко, Ж.-Ж. Ламбен, М. Портер, І. Сіваченко, Г. Скудар, Р. Фатхутдінов, Й. Шумпетер та ін. Основні положення управління конкурентоспроможністю підприємств та організацій представлено в працях [1-12]. Це свідчить про стабільний інтерес до проблем 
конкурентоспроможності у зарубіжній та вітчизняній науці, що пов'язано з практичною цінністю та перспективністю даних досліджень.

Постановка завдання. Метою дослідження $€$ аналіз трактування конкурентоспроможності на основі існуючої науково-економічної літератури, визначення чинників впливу не неї та розроблення рекомендацій щодо вдосконалення управління конкурентоспроможністю підприємства.

Виклад основного матеріалу дослідження. Єдиного підходу до визначення категорії конкурентоспроможності у вітчизняній та зарубіжній науці не існує. Аналіз економічної літератури щодо встановлення змісту поняття конкурентоспроможності свідчить про наявність багатоаспектного трактування цього терміна. За рівнем економічних об'єктів, що конкурують, розглядають конкурентоспроможність країни, галузі, регіону, підприємства, товару.

Конкурентоспроможність підприємства $є$ однією з найважливіших категорій ринкової економіки і характеризує можливість й ефективність адаптації підприємства до умов зовнішнього конкурентного середовища, здатність вступати у конкуренцію на даному ринку та перемагати в ній. Визначення конкурентоспроможності підприємства наведено в табл. 1. Як бачимо, усі автори додержуються думки, що конкурентоспроможність підприємства - це спроможність забезпечувати конкурентоспроможність своєї продукції та послуг, перемагати у боротьбі за ринки збуту. Деякі автори наголошують, що конкурентоспроможність означає також здатність підприємства до ефективної господарської діяльності.

На конкурентоспроможність підприємства впливають внутрішні та зовнішні чинники, які наведено на рис. 1. Чинник - рушійна сила, причина будь-якого процесу, що визначає його характер або одну з основних рис.

Зовнішні чинники поділяються на чинники макрорівня, до яких відносяться економічні, політичні, соціальні, демографрічні, культурні, технологічні, географрічні, екологічні, науково-технічні, епідеміологічні, а також чинники мезорівня, які проявляються як галузеві бар'єри. Це постачальники, споживачі, конкуренти, посередники, держані органи, місцеві громади та ін.

Внутрішні чинники впливу, або чинники мікрорівня, своєю чергою, поділяються на чинники, які відносяться до продукції і послуг, та чинники, які належать до системи господарювання підприємства.

В умовах глобалізації та широкого розповсюдження інфрормаційних технологій забезпечувати конкурентоспроможність підприємству дає змогу вміння еорективно використовувати свої нематеріальні конкурентні переваги. Вагомого значення набувають ті види ресурсів, які не мають матеріальної форми, проте вирішальною мірою впливають на формування результатів діяльності підприємства. Значення матеріальних ресурсів поступово зменшується, тоді як нематеріальних активів, таких як репутація фрірми, імідж підприємства, корпоративна культура, постійно зростає.

Конкурентоспроможність проявляється лише в умовах конкуренції і через конкуренцію [8]. На думку Й. Шумпетера [12], конкуренція - це боротьба старого з новим: нових товарів, нових технологій, нових джерел постачання, нових організаційних орорм та ін.

Таблиця 1

\section{Визначення поняття «конкурентоспроможність підприємства»}

\begin{tabular}{|c|c|}
\hline Автор & Визначення \\
\hline $\begin{array}{l}\text { С.М. Клименко, } \\
\text { Т.В. Омельяненко, } \\
\text { Д.О. Барабась, } \\
\text { О.С. Дуброва, } \\
\text { А.В. Вакуленко [8] }\end{array}$ & $\begin{array}{l}\text { Конкурентоспроможність виявляється лише в умовах конкуренції і через конкуренцію. У } \\
\text { країнах із ринковою економікою конкурентоспроможність підприємства є результатом } \\
\text { переплетіння чинників, породжених об єктивним розвитком продуктивних сил, які відобра- } \\
\text { жають результати політики великих монополій у боротьбі за якість, ринки збуту й отримання } \\
\text { прибутку. }\end{array}$ \\
\hline Р.А. Фатхутдінов [10] & $\begin{array}{l}\text { Конкурентоспроможність - це властивість об'єкта, що характеризується ступенем реаль- } \\
\text { ного або потенційного задоволення ним конкретної потреби порівняно з аналогічними } \\
\text { об'єктами. Конкурентоспроможність визначає здатність витримувати конкуренцію порів- } \\
\text { няно з аналогічними об'єктами на даному ринку. }\end{array}$ \\
\hline І.Ю. Сівачє & $\begin{array}{l}\text { Кожн } \\
\text { пере } \\
\text { ваги }\end{array}$ \\
\hline С.Ф. Покропивний [5] & $\begin{array}{l}\text { Конкурентоспроможність підприємства означає його здатність до ефективної господар- } \\
\text { ської діяльності та забезпечення прибутковості за умов конкурентного ринку. Конкуренто- } \\
\text { спроможність підприємства - це здатність забезпечувати випуск і реалізацію конкуренто- } \\
\text { спроможної продукції. }\end{array}$ \\
\hline $\begin{array}{l}\text { 3.Є. Шершньо } \\
\text { С.В. Оборська }\end{array}$ & $\begin{array}{l}\text { Конкурентоспроможність підприємства - рівень його компетенції відносно інших підпри- } \\
\text { ємств-конкурентів у нагромадженні та використанні виробничого потенціалу певної спря- } \\
\text { мованості, а також його окремих складників: технології, ресурсів, менеджменту (особливо } \\
\text { стратегічного поточного планування), навичок і знань персоналу тощо, що знаходить вира- } \\
\text { ження в таких результуючих показниках, як якість продукції, прибутковість, продуктивність } \\
\text { тощо. }\end{array}$ \\
\hline
\end{tabular}




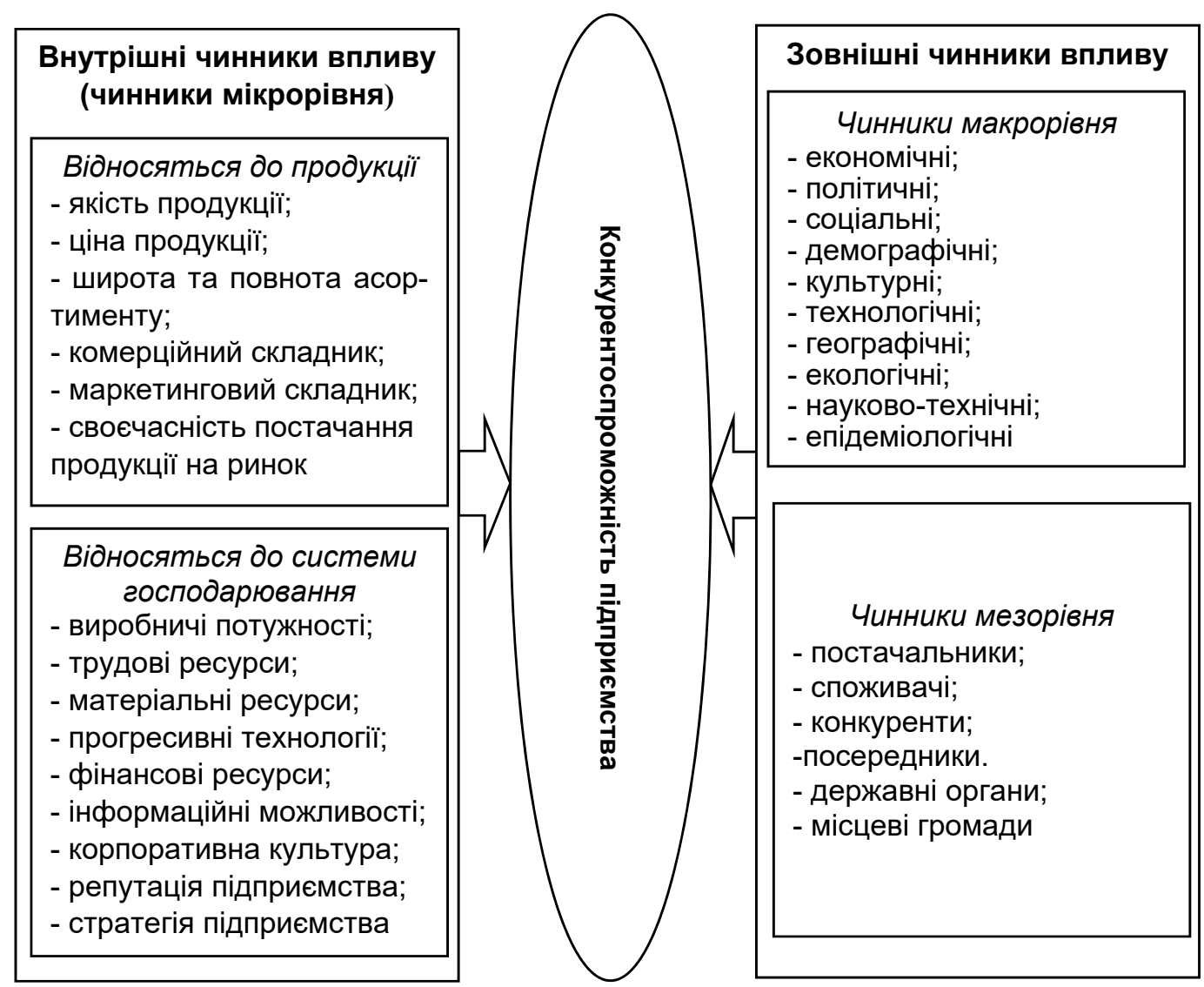

Рис. 1. Чинники впливу на конкурентоспроможність підприємства

Конкурентоспроможність фрормується на етапах життєвого циклу товарів під дією внутрішніх та зовнішніх умов. Але для цього необхідно здійснити впровадження інновацій на відповідному етапі, застосувати щось нове, чого немає у конкурентів. Тому можна стверджувати, що впровадження інновацій - це метод створення конкурентоспроможності підприємства. Висока динаміка економічних процесів, науково-технічного прогресу, інтенсивність конкуренції вимагають від усіх учасників ринку активізації інноваційної діяльності. Розрізняють кілька видів інновацій, які здійснюють підприємства:

- товарна - проєктування та виробництво нових видів продукції;

- технологічна - упровадження нових технологій у виробництво;

- технічна - розроблення та впровадження нових технічних засобів;

- маркетингова - використання нових маркетингових засобів та інструментів;

- управлінська - реорганізація організаційної структури управління підприємством;

- соціальна - розроблення заходів, спрямованих на підвищення якості життя людей;

- екологічна - упровадження заходів 3 охорони навколишнього природнього середовища.

Через важливість конкурентоспроможності для есрективного фрункціонування вітчизняних підпри- ємств необхідно керувати ії рівнем. Управління конкурентоспроможністю $є$ необхідною умовою розвитку підприємства. Для вдосконалення управління конкурентоспроможністю підприємств, на нашу думку, необхідне впровадження таких заходів:

- визначення мети та основних пріоритетів розвитку підприємства;

- проведення аналізу внутрішнього та зовнішнього середовища підприємства, виявлення сильних та слабких сторін, загроз та можливостей;

- оцінка досягнутого рівня конкурентоспроможності продукції та підприємства;

- розроблення та впровадження ефективних стратегії конкуренції та стратегій розвитку;

- упровадження інфрормаційних технологій та широке використання можливостей Інтернету;

- постійний контакт зі споживачами та замовниками продукції або послуг, виявлення їхніх вимог та визначення рівня задоволеності;

- диверсифрікація виробництва продукції або послуг, що допоможе знизити ризики;

- упровадження новацій;

- поліпшення діяльності та процесів підприємства шляхом радикальної перебудови (реінжиніринг) або невеликих постійних поліпшень (кайдзен);

- вчасне виявлення та усунення невідповідностей у продукції або послугах;

- пошук більш вигідних постачальників ресурсів;

- проведення внутрішніх аудитів на підприємстві; 
- розроблення й упровадження ефективної системи управління якістю та інших систем управління;

- охорона довкілля та ін.

Запропоновані заходи з удосконалення управління конкурентоспроможністю стимулюватимуть зміцнення конкурентних переваг підприємства на ринку, а отже, забезпечать перемогу у конкурентній боротьбі, виживання та процвітання на ринку.

Висновки 3 проведеного дослідження. Управління конкурентоспроможністю сьогодні $\epsilon$ одним із центральних питань у функціонуванні підприємства. Конкурентоспроможність підприємства характеризує здатність і ефективність адаптації підприємства до умов зовнішнього конкурентного середовища, здатність вступати у конкуренцію на ринку та перемагати в ній. На конкурентоспроможність підприємства впливають внутрішні та зовнішні чинники, вона фрормується на етапах життєвого циклу товарів під дією внутрішніх та зовнішніх умов. Для цього необхідно здійснити впровадження інновацій, які можуть бути товарними, технологічними, технічними, маркетинговими, управлінськими, соціальними, екологічними та ін. Запропоновані заходи з удосконалення управління конкурентоспроможністю підприємства забезпечуватимуть його конкурентні переваги.

\section{БІБЛІОГРАФІЧНИЙ СПИСОК:}

1. Бондаренко С.М. Ділова досконалість підприємств як фрактор конкурентоспроможності національної економіки України. Економічний простір. 2016. № 116. С. 200-208.

2. Бондаренко С.М., Михайленко Н.В. Базова концепція загальногоуправління якістю TQМ: Роль персоналу. Економічний простір. 2015. № 103. С. 139-146.

3. Бондаренко С.М. Рейтингове управління конкурентоспроможністю продукції промислових підприємств (на прикладі взуттєвого виробництва) : авторефр. дис. ... канд. економ. наук : 08.06.01. Київ, 2002. 18 с.

4. Готь О.Я., Бондаренко С.М. Стратегія підприємства як чинник його конкурентоспроможності. Ефективна економіка. 2017. № 6. URL: http://www.economy.nayka.com.ua/?op=1\&z=5660 (дата звернення: 27.01.2021).

5. Економіка підприємства / за заг. ред. С. Ф. Покропивного. Київ : КНЕУ, 2005. 528 с.

6. Касич А.О., Харькова Ж.В. Управління конкурентними перевагами підприємства. Економічний аналіз. 2016. № 2. С. 79-85.

7. Портер М. Конкурентна стратегія. Техніки аналізу галузей і конкурентів. Київ : Наш формат, 2020. 424 с.

8. Управління конкурентоспроможністю підприємства : навчальний посібник / С.М. Клименко та ін. Київ : КНЕУ, 2008. 520 с.

9. Управління міжнародною конкурентоспроможністю підприємств : навчальний посібник / за ред. І.Ю. Сіваченка, Ю.Г. Козака, Ю.І. Єханурова. Київ : Центр навчальної літератури, 2008. 456 с.

10. Фатхутдинов Р.А. Конкурентоспособность: экономика, стратегия, управление. Москва: ИНФРА-М, 2008. 312 c.
11. Шершньова 3.€., Оборська С.В. Стратегічне управління : навчальний посібник. Київ : КНЕУ, 1999. 384 с.

12. Шумпетер Й. Теорія економічного розвитку. Дослідження прибутків, капіталу, кредиту, відсотка та економічного циклу. Київ : Києво-Могилянська академія, 2011. 244 с.

\section{REFERENCES:}

1. Bondarenko S.M. (2016) Dilova doskonalistj pidpryjemstv jak faktor konkurentospromozhnosti nacionalj-noji ekonomiky Ukrajiny [Business excellence of enterpri-ses as a factor of competitiveness of the national economy of Ukraine]. Ekonomichnyj prostir, no. 116 , pp. 200-208.

2. Bondarenko S.M., Mykhajlenko N.V. (2015) Bazova koncepciya zagal'nogo upravlinnya yakistyu TQM: Rol personalu [Basic concept of total quality management TQM: The role of staff]. Ekonomichnyj prostir, no. 103 , pp. 139-146.

3. Bondarenko S.M. (2002) Reitynhove upravlinnia konkurentospromozhnistiu produktsii promyslovykh pidpryiemstv (na prykladi vzuttievoho vyrobnytstva) [Rating management of competitiveness of products of industrial enterprises (on the example of shoe production)] (PhD Thesis), Kyiv: Kyiv National University of Technologies and Design.

4. Ghotj O.Ja., Bondarenko S.M. (2017) Strateghija pidpryjemstva jak chynnyk jogho konkurentospromozhnosti [Enterprise strategy as a factor of its competitiveness]. Efektyvna ekonomika (electronic journal), no. 6. Available at: http://www.economy.nayka.com.ua/ ?op=1\&z=5660 (accessed 29 January 2021).

5. Pokropyvnyj S.F. (2005) Ekonomika pidpryyemstva [Business Economics]. Kyiv: KNEU. (in Ukrainian)

6. Kasych A.O., Kharkova Zh.V. Upravlinnia konkurentnymy perevahamy pidpryiemstva [Management of competitive advantages of the enterprise]. Ekonomichnyj analiz, no. 2, pp. 79-85.

7. Porter M. (2020) Konkurentna strategiya. Texniky analizu galuzej $i$ konkurentiv [Competitive strategy. Techniques of analysis of industries and competitors]. Kyiv: Nash format. (in Ukrainian)

8. Klymenko S.M. (2008) Upravlinnya konkurentospromozhnistyu pidpryemstva [Enterprise competitiveness management]. Kyiv: KNEU. (in Ukrainian)

9. Sivachenko I.Yu., Kozak Yu.G., Yexanurov Yu.I. (2008) Upravlinnya mizhnarodnoyu konkurentospromozhnistyu pidpryyemstv [Management of international competitiveness of enterprises]. Kyiv: Centr navchalnoyi literatury. (in Ukrainian)

10. Fatkhutdinov R.A. (2008) Konkurentosposobnost': ekonomika, strategiya, upravlenie [Competitiveness: economics, strategy, management]. Moscow: INFRA-M. (in Russian)

11. Shershnova Z.Ye., Oborska S.V. (1999) Strategichne upravlinnya [Strategic management]. Kyiv: KNEU. (in Ukrainian)

12. Shumpeter J. (2011) Teoriia ekonomichnoho rozvytku. Doslidzhennia prybutkiv, kapitalu, kredytu, vidsotka ta ekonomichnoho tsyklu [Theory of economic development. Research of profit, capital, credit, interest and economic cycle]. Kyiv: Vydavnychij dim «KyevoMogylyanska akademiya». (in Ukrainian) 